\title{
A review of the role of submarine canyons in deep-ocean exchange with the shelf
}

\author{
S. E. Allen ${ }^{1}$ and X. Durrieu de Madron ${ }^{2}$ \\ ${ }^{1}$ Department of Earth and Ocean Science, University of British Columbia, 6339 Stores Rd, Vancouver V6T 1Z4, Canada \\ ${ }^{2}$ Centre de Formation et de Recherche sur l'Environnement Marin, CNRS, Universite de Perpignan, 52 Avenue de Villeneuve, \\ 66860 Perpignan, France
}

Received: 31 May 2009 - Published in Ocean Sci. Discuss.: 3 July 2009

Revised: 17 October 2009 - Accepted: 10 November 2009 - Published: 7 December 2009

\begin{abstract}
Cross shelf-break exchange is limited by the tendency of geostrophic flow to follow bathymetric contours, not cross them. However, small scale topography, such as canyons, can reduce the local lengthscale of the flow and increase the local Rossby number. These higher Rossby numbers mean the flow is no longer purely geostrophic and significant cross-isobath flow can occur. This cross-isobath flow includes both upwelling and downwelling due to wind-driven shelf currents and the strong cascading flows of dense shelfwater into the ocean. Tidal currents usually run primarily parallel to the shelf-break topography. Canyons cut across these flows and thus are often regions of generation of strong baroclinic tides and internal waves. Canyons can also focus internal waves. Both processes lead to greatly elevated levels of mixing. Thus, through both advection and mixing processes, canyons can enhance Deep Ocean Shelf Exchange. Here we review the state of the science describing the dynamics of the flows and suggest further areas of research, particularly into quantifying fluxes of nutrients and carbon as well as heat and salt through canyons.
\end{abstract}

\section{Introduction}

It has long been known that the steep topography of the continental slope steers flow along isobaths. Cross-slope flow is inhibited and exchange between the coastal ocean and the deep ocean is limited. For a number of dynamical reasons, under-water submarine canyons can act as conduits, with deep, dense ocean-water moving onto the shelf, or with dense shelf-water cascading to the open ocean, or act as regions of enhanced mixing with focusing and amplification of internal waves. In this paper, we will review what is known about each of these processes and draw attention to what is unknown and requires further research.
Homogeneous, geostrophic flow has zero horizontal divergence (fluid columns cannot change their area as there is no net horizontal flux into or out of them) and thus moves as rigid columns of water, unable to change their length (Taylor, 1923). Such flow cannot change its depth and is constrained to follow isobaths. Stratified flow is similarly constrained up to a depth where there is zero flow (Brink, 1998); above such a depth, the flow can cross the isobaths. Thus a shelfbreak current which extends from the surface to depth, completely blocks even stratified geostrophic flow from crossing isobaths.

Deep ocean shelf exchange (DOES) therefore occurs when and where ageostrophic flow dynamics occur. That is, where friction processes are large, time dependence is important or advection dominates (Allen, 2004). We are looking for times and places where Ekman numbers (ratio of magnitude of friction to Coriolis force), temporal Rossby numbers (ratio of magnitude of time-change to Coriolis force) or Rossby numbers (ratio of magnitude of advection to Coriolis force) are significant. Submarine canyons are regions of enhanced cross-shelf exchange primarily because they are regions of larger Rossby numbers $(R o=U / f L$ where $U$ is a horizontal velocity scale, $f$ is the Coriolis parameter and $L$ is a horizontal length scale). Large Rossby number areas are regions in which the effects of planetary rotation are secondary to the effects of advection of momentum. Over canyons, the characteristic length-scale is reduced from the scale of the slope or shelf, to the scale of the canyon which is often an order of magnitude smaller. In addition, canyons often cause acceleration of nearly geostrophic flow, further increasing the Rossby number. In many regions of the world, numerous canyons cut the shelf-break and incise the shelf (Fig. 1).

\section{Correspondence to: S. E. Allen}

(sallen@eos.ubc.ca)

Published by Copernicus Publications on behalf of the European Geosciences Union. 


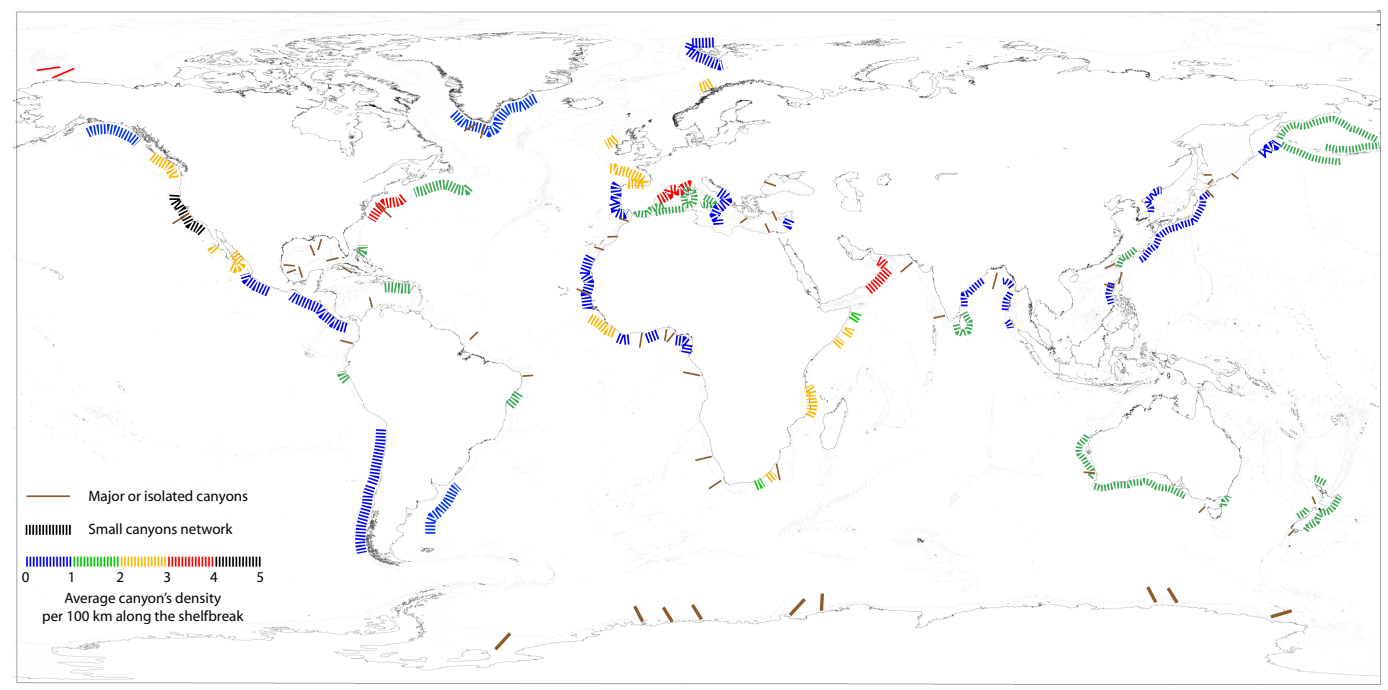

Fig. 1. Density of shelf-break canyons and locations of major canyons. See Appendix B for methodology.

Submarine canyons alter and often enhance ageostrophic processes due to high Ekman or temporal Rossby numbers (e.g. Yuan, 2002; Jordi et al., 2005). However, in this manuscript we will only touch on these dynamics, concentrating instead on those processes that do not occur without the presence of a canyon.

Due to the restriction of geostrophic flow to follow isobaths and aided by the constraints of the coastline, flows over the continental shelf and slope are predominately along the slope. This implies, through geostrophy, a cross-slope pressure gradient. However, deep in a canyon, the flow cannot be along-slope as it is restricted by the canyon walls. Here, the Coriolis force due to the flow cannot balance the large-scale pressure gradient and flow can be down the pressure gradient (Freeland and Denman, 1982, pressure gradient maps in She and Klinck, 2000). This flow is a general geophysical fluid dynamical result and is observed in atmospheric flows (e.g. Whiteman and Doran, 1993) and laboratory flows as well as in the ocean.

Flow within the canyon is dominated by the pressure gradient at the canyon rim and whatever density-generated baroclinic pressure gradients occur within the canyon. The near surface currents are of no direct impact unless they penetrate in depth to the canyon rim. Thus we can separate canyon conduit flow into two types. Wind driven shelf-break or slope currents lead to upwelling or downwelling flows within the canyon with the strongest effects at the canyon rim especially at shelf-break depth. Deep water formation on the shelf similarly leads to strong cross-slope pressure gradients. However, these flows cascade down the canyon, are focused deep, near the canyon axis, and are, in many ways, independent of the wind-driven flows above. This review will consider these two types of dynamics separately.
The problem of the response of real flows (varying spatially and temporarily on various time scales), in complex stratification to the full three-dimensional topography including surface roughness of a real canyon is truly complex. Neither laboratory models (limited by available Reynolds numbers) nor numerical models (limited by computational capacity to resolve boundary layers, advection and the larger flow) can adequately model these real flows. In this review, we will present models based primarily on generic canyons (smooth geometry) in nearly uniform flows, with simplified stratification profiles. We also discuss many of the observations of flow over real canyons. In so far as there is good, but not exact or quantitative agreement, we believe that the dynamical understanding from the simplified models is applicable to real canyon flows.

Throughout this paper, flow in the direction along the shelf/slope that is the same direction as a Kelvin wave propagates will be called "positive along-slope flow" and flow that travels in the opposite direction will be referred to as "negative along-slope flow" (Fig. 2). Generally negative flows are associated with net upwelling (upward flow and flow toward the coast) and positive flows are associated with net downwelling (downward flow and flow toward the ocean). Net fluxes to or from the ocean can be accommodated by changes in the along-shelf current flux (Fig. 2).

\section{Canyon-driven upwelling/downwelling}

\subsection{Phasing of canyon flow}

A typical upwelling or downwelling scenario over a canyon can be broken down into 3 phases: an initial time-dependent response as the shelf-break flow increases, an advection dominated response during the time when the shelf-break flow 


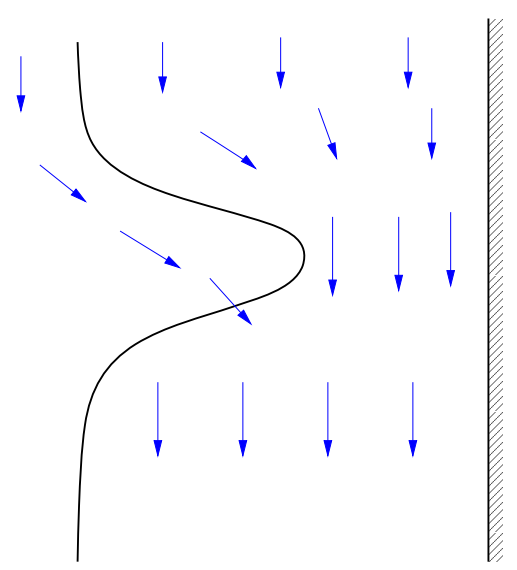

Fig. 2. Plan view sketch showing net flux through a canyon onto the shelf accommodated by an increasing along-shelf flux. Black line is the shelf-break isobath, straight hatching on right is the coast and the blue arrows represent the flow with length representing the strength of the flow. The flow shown is negative in the Northern Hemisphere and positive in the Southern Hemisphere.

is reasonably steady and a relaxation phase when the shelfbreak flow decreases.

The time-dependent response is generally strong and occurs quickly: within an inertial period (Klinck, 1988; Kämpf, 2006). If the along-shore current continues to increase, say due to steady winds, density advection within the canyon reduces time-dependent upwelling after about 5 days (She and Klinck, 2000). The advection dominated response is strongly dependent on the canyon topography and flow strength (Allen, 2004). For weaker flows it can be greatly enhanced if strongly convergent isobaths occur over the canyon (Allen, 2000; Waterhouse et al., 2009). The final relaxation phase sees strong, generally cyclonic flow within the canyon (Hickey, 1997).

\subsection{Asymmetry of canyon driven upwelling/ downwelling}

The initial time-dependent response is essentially linear and similar for negative and positive flows until significant density advection occurs. The second, advection-dominated phase is clearly not linear. Upwelling is generally stronger than downwelling (Klinck, 1996; She and Klinck, 2000). Downwelling is driven by positive flows which are in the same direction as shelf-waves propagate. Thus they do not impede the shelf-waves and allow along-isobath flow to be established by the waves even around the canyon. On the other-hand, upwelling flows oppose the shelf-waves and can arrest them. This leads to stronger cross-isobath flow over canyons.

This asymmetry between upwelling and downwelling naturally leads to mean flows created by oscillatory flows over a canyon. In the positive phase of an oscillatory flow, the flow diverges from the upstream wall and flows out of the

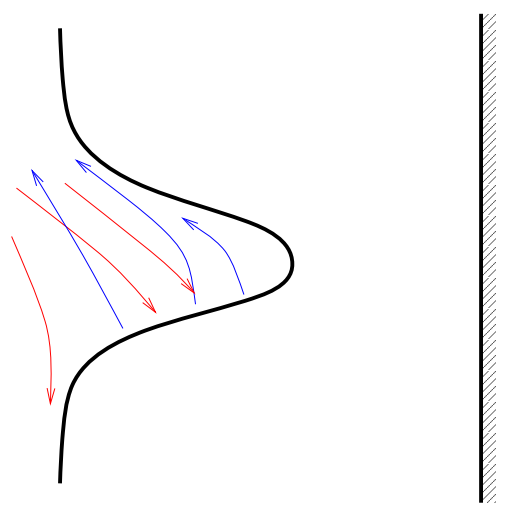

Fig. 3. Plan view sketch showing differences between the positive (blue) and negative (red) phases of oscillating flow for the Northern Hemisphere. Based on laboratory observations in Fig. 7 of Perenne et al. (2001a). Black line is the shelf-break isobath, straight hatching on right is the coast and the blue and red arrows represent positive and negative phase flow, respectively.

canyon along the downstream wall (Perenne et al., 2001; Fig. 3). In the negative phase, the flow follows the upstream wall into the canyon and upwells along the downstream wall (ibid.). Above shelf-break depth there is a net flux into the canyon and below shelf-break depth a mean positive flow enters and exits the canyon (ibid.). Net upwelling occurs throughout the canyon for weakly stratified flows, with maximum upward velocities at the shelf-break depth (Boyer et al., 2006). Analysis of numerical model results show large dense lenses of upwelled water on both sides of the canyon (Haidvogel, 2005). More recent numerical results show weaker upwelling than implied by the laboratory experiments (Kämpf, 2009) perhaps due to stronger stratification but most likely due to a stricter definition of upwelling flux (requiring water from $100 \mathrm{~m}$ below the shelf-break).

The scale of the residual velocity depends upon the strength of the oscillatory velocity and the Coriolis parameter and inversely on the oscillatory frequency, the stratification and the viscosity (Boyer et al., 2004). The effect of canyon geometry is yet to be determined (Boyer et al., 2006). Interestingly the flow showed little qualitative change as the frequency was changed from sub-inertial to superinertial (Boyer et al., 2006; Haidvogel, 2005). However the mean flows are significantly stronger for subinertial oscillations (Boyer et al., 2000). For typical laboratory and oceanic values, residual currents on the order of $15 \%$ of tidal flows could be expected (Boyer et al., 2004). Flows with full turbulent boundary layers have weaker residual velocites as the basic balance is between vorticity generation by stretching and dissipation due to viscosity or turbulent mixing (Boyer et al., 2006). In the oscillatory case, because the basic balance includes it, accurate turbulent dissipation modelling is required for quantitative estimates of the residual velocity and total fluid upwelled onto the shelf. 


\subsection{Vertical structure of canyon driven upwelling}

In upwelling/downwelling the response can be divided by depth layers (She and Klinck, 2000; Allen, 2004). Near the surface the flow is only weakly affected by the canyon (Hickey, 1997; Palanques et al., 2005). How far up above the canyon the topography is "felt" will be a function of stratification and the size of the canyon. However, generally, flow more than $100 \mathrm{~m}$ above the shelf travels over the canyon relatively unaffected by it.

For upwelling which is generated by negative along-slope flows, flow over the shelf (above the boundary layer) flows over the upstream rim of the canyon. If the flow is very weak, it will turn inshore to follow the topography. For strong flows it tends to turn slightly offshore (Hickey, 1997; Dawe and Allen, 2008). As this flow crosses the rim of the canyon it drops down into the canyon and is stretched (Hickey, 1997; Allen et al., 2001; Boyer et al., 2004). A clear illustration of this effect is seen in Fig. 12 of Hickey (1997). The stretched flow gains positive vorticity, turning it up canyon. It flows toward the head of the canyon and over the downstream rim (Klinck, 1996 in particular, Fig. 4a). As the flow upwells over the downstream wall, it is again squashed and generates anti-cyclonic vorticity (Allen, 1996).

Flow over the upper slope near rim-depth is advected into the canyon (Klinck, 1996; Perenne et al., 2001b). This is the deepest water that is advected onto the shelf. Flow near rimdepth is substantially stretched and can form a closed eddy (Hickey, 1997; Allen et al., 2001). However, cyclonic vorticity is also generated in the slope flow due to friction against the slope (Perenne et al., 2001b). There is some evidence that this latter vorticity may be less important than stretching (Flexas et al., 2008; Waterhouse et al., 2009). These vorticity patterns, with strong cyclonic vorticity (under both upwelling and downwelling) are for near uniform shelf flows. Anticyclonic vorticity in the mean flow, where the mean flow is jet-like, can cause anti-cyclonic eddies within the canyon (Ardhuin et al., 1999).

Flow deeper in the canyon is stretched and forms a cyclonic eddy deep in the canyon (Allen, 1996; Hickey, 1997).

\subsection{Role of bottom boundary layer}

Some studies have postulated (Allen, 1996) or numerically simulated (Kämpf, 2006) strong steady upwelling flow through the bottom boundary layer. This process (and its reverse for downwelling) may be important in gently sloping canyons (more like troughs) or in weakly stratified regions. In canyons with typical slopes and strong stratification $\left(>5 \times 10^{-3} \mathrm{~s}^{-1}\right)$, the boundary layer over the canyon walls and along the axis, for steady flow, should be arrested within a day (see Appendix A).

Even for steady flow, the boundary layer on the shelf is not expected to shut-down. Strong boundary layer flow can reduce the geostrophic along-shelf flow and thus reduce the strength of the pressure gradient driving canyon upwelling/downwelling (Jaramillo, 2005). The most detailed study of the impact of the boundary layer (in this case a turbulent boundary layer) on canyon flow was done for the oscillatory case (Boyer et al., 2006).

For oscillatory flow, the boundary layer will not arrest in the classic way and friction plays an important role in the amount of water upwelled (Boyer et al., 2004). For the case of dense water cascading down a canyon (discussed in Sect. 3), the cascading water is well-mixed and so the boundary layer will not arrest in the classic way. In this case as well, the dynamical balance is linked to friction processes (Wåhlin, 2002).

\subsection{Converging isobaths}

Geostrophic flow over converging isobaths will accelerate and can accelerate to the point where the flow is no longer geostrophic and crosses the isobaths (Allen, 2000). This convergence leads to upwelling particularly in long canyons that closely approach the coast (Allen, 2000) even if these canyons are very wide and trough-like (Yuan, 2002). Upwelling tends to occur at the converged isobaths whether they occur near the head of the canyon (Yuan, 2002) or near the mouth (Waterhouse et al., 2009). Some of the clearest observations of enhanced upwelling near isobath convergence is seen at the head of Bio Bio Canyon (Sobarzo et al., 2001).

\subsection{Time-dependent flow: wind bursts and flow relaxation}

As geostrophic flow increases in a negative direction along the slope due to a wind burst, or due to relaxation of a positive wind stress, an ageostrophic on-shore velocity is generated. This ageostrophic flow is concentrated to flow through the canyon (Allen, 1996). If time-dependent upwelling is occurring it can be very strong and dominate over advection-driven processes. A clear example of this comes from a numerical model of Calvi Canyon. A NW wind-stress is upwelling favorable and even though it acts against the mean flow and merely reduces the mean flow but does not reverse it, strong upwelling is seen in the canyon (Skliris et al., 2001). This effect is also seen over Blanes Canyon although with some reversal of the shelf-flow near the coast (Ardhuin et al., 1999). Downwelling patterns are seen over Astoria Canyon during upwelling wind relaxations (Hickey, 1997). Time-dependent flow patterns appear to dominate over advection flow patterns for weak flows in the laboratory (Waterhouse et al., 2009).

\subsection{Observations of upwelling/downwelling in canyons}

Although collection of observations over the steep topography of submarine canyons is difficult (Hickey, 1995) and many current meters are removed by fishers (Allen et al., 2001), a number of studies have been made. Freeland and Denman (1982) used water property observations over 
Juan de Fuca Canyon to identify strong upwelling during negative (summer) flow periods. A similar set of observations was used to show upwelling in Mackenzie Canyon of up to $1000 \mathrm{~m}$ (Carmack and Kulikov, 1998). Both Juan de Fuca and Mackenzie Canyons are long canyons and should have stronger upwelling responses due to converging isobaths (Allen, 2000).

The most detailed set of observations was made over Astoria Canyon (Hickey, 1997) including both a fine scale CTD (conductivity - temperature - depth + transmissometer) survey and long-term current meters. Complete upwelling episodes were captured and detailed flow structures during the episode and during relaxation were made. A smaller survey was made over Barkley Canyon showing similar but less strong phenomena (Allen et al., 2001); Barkley Canyon is a considerably smaller canyon than Astoria Canyon. Upwelling over a very wide canyon was observed over Quinault Canyon (Hickey et al., 1986). A brief upwelling interlude over Carson Canyon, a canyon usually in a positive flow field, has been documented (Kinsella et al., 1987). A study over a canyon off the west coast of Africa shows the strong response within a canyon with a low Coriolis parameter (Shaffer, 1976). In the Arctic, strong coupling between wind and ice and ice and water has been shown to lead to very strong upwelling through submarine canyons (Williams et al., 2006).

Canyons in the Mediterranean are generally under the influence of positive flows and thus downwelling. Near-bottom currents are observed to be constrained to the topography as expected and closed circulations are observed in the canyons (Palanques et al., 2005). Especially when considering the deeper parts of the canyon $(>1200 \mathrm{~m})$, near surface flow is unaffected by the underlying topography under real stratifications (Palanques et al., 2005). Flow across the canyon leads to localized upwelling on its downstream side with downwelling on the upstream side (Flexas et al., 2008). Surprisingly, over Blanes Canyon, net upwelling has been observed in at least two seasons below the thermocline (Flexas et al., 2008) and although numerical studies show similar flow pattern, they consistently show net downwelling for positive flows (Jordi et al., 2008).

A mid-depth (200 m) meander over Palamos Canyon was observed to have flow that looked like the type of flow seen during positive flow over a canyon (Pascual et al., 2004). However, on balance the authors felt that the position was a coincidence and that the meander was a baroclinic instability of the shelf-flow. Over the canyon, in the middle of the cyclonic part of the meander, vertical velocities were upward except deep in the canyon. These upward velocities were linked to vorticity-advection well above the topography as opposed to a flow/topography interaction which was seen deeper in the canyon.

During a strong offshore wind event (a Mistral wind), upwelling between 100 and $250 \mathrm{~m}$ was observed in GrandRhône canyon (Durrieu de Madron, 1992). Usually, like other Mediterranean canyons, this canyon is under the influence of a negative along-slope flow and general downwelling with the canyon. Daily mean vertical velocities for this canyon have been estimated at $60 \mathrm{~m} \mathrm{day}^{-1}$ (Durrieu de Madron et al., 1999).

A study over Perth Canyon illustrates the important role that the currents at the rim-depth play in generating strong responses within the canyon (Rennie et al., 2006). Because the dominant, strong, Leeuwin Current is surface trapped and only weakly extends to $250 \mathrm{~m}$ whereas the shelf-break depth is close to $200 \mathrm{~m}$, coupling of the current to the canyon is weak and changes in the vicinity are determined primarily by direct changes in the Leeuwin Current (Rennie et al., 2006). A similar effect is seen over Palamos Canyon. Flow over this canyon is usually confined to a surface intensified jet. Interaction with the canyon is stronger when the jet occurs in shallower water over the head of the canyon, than in deeper water over the mouth (Alvarez et al., 1996).

Rim-depth currents are also strongly affected if the canyon occurs within a bay. Monterey Canyon is contained within Monterey Bay, a region with relatively weak currents. Thus even though Monterey Canyon is a long canyon, canyondriven upwelling is weak (Rosenfeld et al., 1994). Upwelling in the long Bio Bio Canyon is strong but complicated by the complex currents occurring within Arauco Bay (Sobarzo et al., 2001). Perhaps uniquely, Barrow Canyon is dominated by a strong down-canyon flow caused by the Bering Strait through-flow (Münchow and Carmack, 1997).

\subsection{Numerical models of upwelling/downwelling in canyons}

Many numerical studies of the various aspects of shelf-flow driven upwelling and downwelling over canyons have been done. As canyons are regions of steep, rapidly changing topography and in the strongly stratified coastal ocean, accurate numerical simulation is difficult (Haney, 1991; Allen et al., 2003; Boyer et al., 2004; Dawe and Allen, 2008) and complicated by open boundary conditions (Dinniman and Klinck, 2002). However much of what we know about the response of flows to submarine canyons has come from numerical studies. These divide into two main groups: process studies over simplified canyon topographies and studies of specific canyons.

Numerical process studies include the pioneer twodimensional study (Klinck, 1989) and early layered models (Chen and Allen, 1996; Allen, 1996). Full three-dimensional studies of both upwelling and downwelling for steady forcing followed (Klinck, 1996; She and Klinck, 2000) and for variable or transient forcing (Jordi et al., 2005; Haidvogel, 2005; Kämpf, 2006, 2007, 2009). Numerical models of laboratory experiments to verify the numerical algorithms have been successful over gently sloping canyons qualitatively 
(Perenne et al., 2001a) but not quantitatively (Boyer et al., 2004). Over steeper canyons even qualitative differences are seen (Allen et al., 2003; Dawe and Allen, 2008).

The simulation of upwelling over specific canyons has not been published. Preliminary results for Astoria Canyon showed difficulty in reproducing the observations (Klinck et al., 1999). Simulations over primarily downwelling canyons show many of the complications of real topographies: changes in shelf width at Blanes Canyon (Ardhuin et al., 1999) and at Palamos Canyon (Jordi et al., 2005) interaction with a bay at Calvi Canyon (Skliris et al., 2001, 2002) and asymmetrical canyon shape at Blanes Canyon (Ardhuin et al., 1999). They have also shown the importance of jet-like shelf flows (Ardhuin et al., 1999; Jordi et al., 2005) and short wind-bursts (Ardhuin et al., 1999; Skliris et al., 2001, 2002).

\subsection{Laboratory models of upwelling/downwelling in canyons}

Laboratory models of flow through canyons have been used because of questions on the accuracy of numerical models (Haidvogel and Beckmann, 1995) particularly concerning advection. Models of oscillatory flow (e.g. Boyer et al., 1991; Perenne et al., 2001a; Boyer et al., 2006) have clearly shown net upwelling over the canyon. Models of upwelling episodes over canyons have been used both to estimate upwelling flux through a canyon (Mirshak and Allen, 2005) and to test numerical models (Perenne et al., 2001a; Allen et al., 2003).

Laboratory models are limited by the size they can be built and thus the maximum Reynolds number that can be modelled. Matching the Reynolds number between the laboratory and the real world can be necessary to correctly model the turbulent dissipation. For steady upwelling/downwelling flows frictional process due to turbulent dissipation are not important to first order, as discussed above, but for other flows such as oscillatory flow over canyons, they are (Boyer et al., 2004).

\section{Role of submarine canyons on dense shelf water cascading}

\subsection{Formation of dense water on shelves}

The mechanism of dense water cascading, is a near-bottom gravity current, where the dense water, originating from cooling, evaporation, freezing and salinization on the continental shelf overflows the shelf edge and flows along the continental slope until its density reaches the ambient density (hydrostatic equilibrium level). Cascading occurs when denser shelf water is forced over the shelf edge by external forcing, such as a downwelling favorable wind or alongslope flow, unsteady continental shelf waves, eddies, and tides.
This current produces an irreversible exchange of shelf water to the basin. This phenomenon has been identified in about 70 sites around the world (Killworth, 1983; Ivanov et al., 2004; Durrieu de Madron et al., 2005). It is found primarily in polar regions and mid-latitude regions, and more scarcely in tropical and subtropical regions. Temperature cooling drives the formation of dense water in all climate zones, while salinity that either fosters or hampers the cascading is generally secondary (Ivanov et al., 2004). Furthermore suspended sediment can have a significant influence upon the density of the bottom water and intensifies the downslope cascading process, increasing the equilibrium depth and eventually provoking ascendant convection of the dense water plume after deposition of the particulate load (Fohrmann et al., 1998; Kämpf et al., 1999).

Dense shelf water cascading contributes to the ventilation of intermediate and deep waters of the oceans and has a significant impact on biogeochemical cycles by entraining significant quantities of minerals and organic material both dissolved and particulate (Hill et al., 1998; Niemann et al., 2004; Canals et al., 2009; Vilibic and Santic, 2008).

\subsection{Influence of canyons - theoretical, laboratory and field studies}

The influence of submarine canyons has received particular attention in the past years, and observation as well as laboratory and numerical modelling studies clearly showed their importance in enhancing ocean-shelf exchanges.

\subsubsection{Observations}

There is a growing number of in situ observations of the dense shelf water transport through canyons and its subsequent dispersal along the slope. However, due to seasonal intermittency and the interannual variability of the mechanism, the average export rates are difficult to assess and are still scarce. For most of them, observations were coupled with 3-D numerical modelling using realistic forcing and topography. These models allow investigation of the details and emphasizes the influence of topographic features upon the flow patterns, the changes in the geometry of the dense water plume and the mixing with surrounding waters. In some canyons, the occurrence of dense water bottom flows could be inferred from peculiar bed depositional and erosional bedforms, such as fields, moats, furrows and comet marks (Canals et al., 2006; Puig et al., 2008; De Santis et al., 2007; Trincardi et al., 2007).

Studies performed in the Mediterranean Sea reveal the prevalence of canyon-driven dense-water cascading. In the western Mediterranean, dense shelf water has been shown to be formed on the Gulf of Lion and adjacent Catalan shelves (Dufau-Julliand et al., 2004; Canals et al, 2006; Ulses et al., 2008a and the references therein). Both observations and modelling show the influence of canyons, in particular the 
Cap de Creus Canyon which channeled most of the dense water formed on these shelves. Hence, for the 2005 severe cascading event, flow through canyons during the cascading period amounted to about $0.2 \mathrm{~Sv}$ and comprised $90 \%$ of the total dense shelf water export. Ulses et al. (2008b) also documented the reinforcement of the dense water overflow by storm-driven downwelling. In a review of dense water generation and spreading on the Adriatic shelf, Vilibic and Supic (2005) reported that the dense shelf water formed in the shallow northern area flows along the western coast and cascades toward the southern Adriatic Pit. The Bari canyon is recognized as a major path for the dense water outflow to the deep basin (Bignami et al., 1990; Trincardi et al., 2007). Transport of North Adriatic Dense Water, which amounts to about $0.1 \mathrm{~Sv}$ hence contributes to the formation of deep water in the Eastern Mediterranean.

In the Arctic, Storfjorden, south of Svalbard, and Barrow Canyon, along the northern Alaskan coast, are well documented areas with production of brine-enriched dense water from winter coastal polynyas. In the Storfjorden, the dense water filling the fjord and subsequently spilling out of the sill descends towards the shelf break and eventually cascades down the slope. The Storfjorden overflow was first observed in the deep Fram Strait by Quadfasel et al. (1988). The spreading and mixing of the dense water plume flowing from the Storfjorden was more recently studied by Schauer and Fahrbach (1999), Fer et al. (2003) and Fer and Adlandsvik (2008). Skogseth et al. (2005) estimated the transport of dense overflow water during the freezing period to be $0.06-$ 0.07 Sv. Recently, Geyer et al. (2009) showed from a pluriannual monitoring that the overflow lasted on average about 6 months, and estimated that the average outflow transport was about 0.03 Sv. Aagaard and Roach (1990) and Weingartner et al. (1998) showed that Barrow Canyon along the northern Alaskan coast represented a major pathway of dense waters formed on the Chukchi shelf. The dynamics of the dense water plume through the canyon was studied by Pickart et al. (2005). They showed that cyclonic relative vorticity, due to stretching of the plume, generated baroclinic instability and eddy formation at the mouth of the canyon. They measured a transport of dense bottom water through Barrow Canyon of $0.2-0.3 \mathrm{~Sv}$.

In the Antarctic, the Ross Sea and the Weddell Sea are the two main sources of Antarctic Bottom Water induced by convergence and accumulation of brine-enriched shelf water over wide shelves (Baines, 2006). The continuous yearround cover by ice in the Ross and Weddell seas has prevented detailed observation of the bottom topography and hence an estimate of the significance of canyons on the descent of dense water along the slope. Nevertheless, Rubino et al. (2003) suggested from hydrological and modelling studies that the off-shelf transport of Deep Ice Shelf Water in the Ross Sea may be controlled by submarine canyons. This was confirmed by Gordon et al. (2009), who showed that several troughs (Drygalski, Joides, Glomar Challenger) along the northwestern continental slope of the Ross sea represented major pathways for the export of dense shelf waters (either High Salinity Shelf Water or Cold low-salinity Ice Shelf Water). It was further demonstrated that tides significantly increased the outflows of dense water, primarily through an increase in benthic layer thickness (Padman et al., 2009). Darelius et al. (2009) and Wang et al. (2009) suggested that the path and mixing of the Filchner overflow plume of cold and dense Ice Shelf water formed in the southwestern Weddell Sea is significantly influenced by smallscale topography, mostly formed by submarine ridges. Huhn et al. (2008) also suspected canyons to be a possible pathway for Ice Shelf Water formed in the Western Weddell Sea.

The Adélie Land is recognized as an important source of Antarctic Bottom Water triggered by strong katabatic winds blowing over the coastal polynya. Williams et al. (2008) indicated that dense water that accumulates in the Adélie depression on the shelf, eventually spills out onto the slope through a narrow sill. The dense shelf water export was estimated $0.1-0.5 \mathrm{~Sv}$.

On the George V Land continental slope, east of the Ross Sea, De Santis et al. (2007) inferred that cold dense bottom cascades could prevent deposition of sediment and exhumation of relict geological features in the Jussieu and Wega canyons.

\subsubsection{Numerical simulations and laboratory experiments}

A review of earlier modelling works of dense water overflow over constant slope has been made by Davies and Xing (2005). The rate of descent of a bottom dense water plume is determined by entrainment, bottom friction and earth rotation which give rise to an Ekman bottom boundary layer. The magnitude of the downslope current depends on the density difference between the dense and ambient waters and slope angle. The role of stratification of ambient waters is key to the fate of the dense water plume on the slope. It is worthy to note that several works studied the effect of ridges, together with that of canyons (Darelius and Wåhlin, 2007; Darelius, 2008; Wåhlin et al., 2008). They show that ridges intercepting the slope appear to be more effective in channeling the dense water downslope.

Chapman and Gawarkiewicz (1995) examined numerically the influence of a canyon cutting across a uniformly sloping shelf, upon the offshore transport of dense water formed on the shelf in front of the canyon. They show that a portion of the dense water formed on the shelf cascades into the canyon, forming a plume that flows offshore along the canyon axis while banked against its right side of the canyon. They also show that eddies, that formed along a sharp density front at the shelf edge may slump into the canyon and disrupt the dense water plume, hence inducing significant spatial and temporal variability. 
Kremenetskiy et al. (2004) experimentally compared the influence of a canyon on the structure and dynamics of frontal current and downslope Ekman layer flow. Whereas, in the absence of the canyon the downslope Ekman layer flow was continuous along the sloping bottom, in the presence of the canyon the velocity of fluid above the canyon was significantly reduced. As a result the downslope Ekman layer flow velocity in the presence of a canyon was smaller. A considerable part of this flow was trapped by the canyon at its downstream wall and propagated downward as a jet along the axis of the canyon. At the upstream wall of the canyon the direction of the bottom Ekman layer flow was upward and weaker.

Wåhlin (2002) considered the steering influence of a submarine canyon on a dense bottom current flowing along the continental shelf. The magnitude of the downslope current is significantly influenced by the presence of the canyon, It drains part of the along-slope transport and dense water can thus converge and accumulate within the topographic depression. The rate at which water is drained from the alongshelf flow is determined from the canyon's geometry and the magnitude of bottom friction. If the along-shore transport upstream of the canyon exceeds the draining capacity of the canyon, the plume divides into two branches. A portion of the flow is then steered down into the canyon while the rest continues on the downstream side of it. Splitting of the gravity current, when the transport capacity of the canyon is exceeded, was also observed by Darelius (2008). Wåhlin (2004) further showed that transport capacity is larger for deep channels than for shallow ones, but that transport also depends on their width. On gently sloping topography a maximum downward flow is induced by rather wide canyons (tens of $\mathrm{km}$ across), but in steeper regions the most active canyons are only a few $\mathrm{km}$ wide. The impact of multiple channels on the descent of dense water was examined by Kämpf (2000). He showed that the net downslope density flux resulting from these circulations exceeds that of flow of dense water developing without channels and that interaction of adjacent channel plumes leads to complex bottom-parallel circulations.

Wåhlin et al. (2008) subsequently performed a set of laboratory experiments to investigate the effect of v-shaped canyon topography and different flow regimes (laminar, waves, and eddies) on plume mixing. They show that, in the presence of a canyon and with respect to the smooth slope, the dense plume was steered downslope and instabilities developed along the canyon walls, and that total mixing and the entrainment rate increased. This happened regardless of the flow characteristics, indicating that it was the small-scale topography and not the large-scale characteristics of the flow that determined the mixing.

Chapman (2000) examined the influence of an ambient along-shelf current on the offshore transport of dense water formed on the shelf upstream of a canyon cutting the slope. They considered the influence of three canyon orientations: normal, diagonal and parallel to the coast. They calculated that little dense water enters a canyon oriented normally or diagonally to the coast, because of the tendency of ambient along-slope flow to follow isobaths and force dense water to by-pass the canyon, but that an appreciable fraction of dense water may flow down a canyon oriented parallel to the coast. The magnitude of the ambient current however play an important role, as swift ambient currents appear to reduce the downcanyon flow of dense water, whereas slower ambient currents are more favourable to downcanyon dense water flow.

Shaw and Chao (2003) numerically showed strong interactions between a dense water bottom plume flowing downcanyon and a baroclinic along-slope current. The dense water plume leaves the canyon at its equilibrium depth, and gives rise to a undercurrent primarily flowing along the isobaths. Eddies subsequently break away from the plume and enter the deep ocean. They showed that, in the presence of an existing ambient slope current, there is a mutual strengthening of the eddy formation and an increase in sinking depth of the dense water plume.

Kämpf (2005) calculated that dense-water cascading down a submarine canyon induces localized upwelling of deeper water onto the shelf. This process is associated with internal deformation radii inherent in the cascading process being less than the canyon width and the geostrophic adjustment of a density front that establishes along the canyon axis.

Guan et al. (2009) analytically and numerically examined the effect of tides on dense water flow. They showed that tide-induced shear dispersion would augment the benthiclayer thickness to significantly enhance the spread of dense water on the shelf and its descent down the continental slope.

Kämpf et al. (1999) examined the role of dense water cascading on the sediment dynamics in the canyons, and was able to reproduce some remarkable morphological characteristics such as deposition zones at the base of canyons and the levees on both sides of the deep channel.

\section{Enhanced internal tides and mixing in canyons}

The previous two sections have discussed advective transport between the deep ocean and the shelf. Additional transport can occur due to deep water entering into canyons (at its ocean depth) and then being mixed up onto the shelf. This process is enhanced by canyons both because they conduct the deep water further onto the shelf than occurs for a straight coastline and secondly because they are regions of enhanced mixing, particularly due to tides.

Some canyons/troughs cut long distances through continental shelves. Examples include (1) Juan de Fuca canyon into the Strait of Juan de Fuca and through to the San Juan/Gulf Islands and (2) the Laurentian channel which cuts through the Gulf of St Lawrence to the Saguenay region. At depth these troughs contain ocean water, which is thus 
carried across the shelves. The head of these troughs enter into large estuaries and thus have large tidal flows along the axis of the canyon and across the head. Thus at the head of these troughs, intense tidal mixing occurs and these regions are both strong nitrate sources to shelf water (Crawford and Dewey, 1989; Saucier, 2000).

Canyons which do not enter into large estuaries, do not tend to have tidal currents along the axis of the canyon, but rather across the canyon and in the direction parallel to the shelf-break. A number of long canyons of this type have been observed to have high to very high internal tidal energy: Hydrographer Canyon (Wunsch and Webb, 1979), Hudson Canyon (Hotchkiss and Wunsch, 1982), Monterey Canyon (Petruncio et al., 1998; Kunze et al., 2002; Carter and Gregg, 2002), La Linea Canyon (Lafuente et al., 1999) Gaoping Canyon (Lee et al., 2009) and the Gully (B. Greenan, personal communication, 2007, Bedford Institute of the Oceanography, Nova Scotia, Canada). Canyons can act to enhance tidal and internal wave energy due to focusing (Wunsch and Webb, 1979) or due large regions of critical slope (Hotchkiss and Wunsch, 1982). It has also been proposed (based on observations in Monterey Canyon) that small scale roughness in the canyon is responsible for much of the internal tidal energy (Kunze et al., 2002). Internal waves with periods shorter than that of tides are also enhanced in canyons and have been hypothesized to be generated by the tides (Bruno et al., 2006). In contrast, nearinertial energy is not enhanced by canyons probably due to the canyon walls interfering with these long wavelength waves (Wunsch and Webb, 1979; Keen and Allen, 2000). Due to the enhanced internal wave and tidal energy, the amount of mixing present in canyons is extremely large; values of diffusivity of $0.05 \mathrm{~m}^{2} \mathrm{~s}^{-1}$ near the canyon axis and values only a factor of 10 smaller extending up to the rimdepth have been measured in Monterey Canyon (Carter and Gregg, 2002; Gregg et al., 2005).

Numerical modelling of internal waves in canyons has proved difficult. Two models of the well studied Monterey Bay Canyon have been done. The earlier model captured much of the qualitative structure of internal tides in the canyon including up-canyon energy propagation and bottomintensified currents within the canyon but simulated velocities were too small by almost an order of magnitude (Petruncio et al., 2002). The most recent study used non-hydrostatic dynamics and included the along-coast tidal component. Simulated velocities were similar to data but energy fluxes were still about five times too small in the canyon model compared to observations (Jachec et al., 2006).

\section{Unanswered questions}

\subsection{Canyon-driven upwelling/downwelling}

Much progress has been made on characterizing upwelling and downwelling regimes over canyons in the last two decades. In the next decade we need to move forward in characterizing the net effect of canyons on shelf-break exchange. To proceed we need to (1) characterize the dynamical regime in terms of non-dimensional numbers, (2) test these values with regards to the complexity of real canyons by either using careful observations or validated numerical models, and (3) move toward characterizing the exchange of tracers (heat, salt and more importantly nutrients, carbon) instead of simply water flux.

Process studies in the laboratory and using numerical models have been used to characterize the dynamical regime. Increased stratification weakens the vertical motions over canyons (Klinck, 1996; Skliris et al., 2002). Dependency of vertical velocity to one over the Brunt-Väisälä frequency has been found in laboratory experiments (Boyer et al., 2004; Mirshak and Allen, 2005) and numerical models (Kämpf, 2007) or to one over the square of the Brunt-Väisälä frequency (Haidvogel, 2005). Due to the importance of advection, the total flux through the canyon increases more quickly than the along-shelf velocity: for upwelling, using laboratory model, to the $8 / 3$ power (Mirshak and Allen, 2005) or using a numerical model, squared (Kämpf, 2007). For oscillatory flow the total flux through the canyon is proportional to the velocity squared (Haidvogel, 2005). The dependence on the Coriolis parameter $(f)$ is controversial. For advectiondriven upwelling, laboratory experiments give flux inversely proportional (to the two-thirds power) on $f$ consistent with the strong upwelling seen over a canyon near the equator (Shaffer, 1976) whereas a numerical model gives upwelling flux proportional to $f$ (Kämpf, 2006). For oscillatory flow over canyons, flux is found to be inversely proportional to $f$ (Haidvogel, 2005). Dependence on geometry, including the effects of the continental shelf slope, has been well less studied. Further work is needed to remove the ambiguities in the characterization of upwelling, add the geometric effects to oscillatory flow, and downwelling remains to be estimated. Numerical modelling is an obvious method to proceed but one must ensure that models are validated carefully against good observational data or laboratory models. Numerical modelling of advective processes in stratified fluids over steep topography requires strict attention to detail. In addition, for oscillatory flow and cascading flows where friction processes appear to first order in the dynamics, the complexities of turbulent Ekman layers must be correctly captured.

The characterization of the dynamics for generic canyons needs to be tested against real canyons with complicated topography, real stratification that varies in depth, complicated incoming currents and with bottom roughness at all scales. 
How well we can predict flows and, in particular fluxes, over real canyons based on generic canyons is yet to be determined. However the qualitative agreement between observational studies and the models gives us confidence that most of the dynamics translates. For specific canyons flux estimates for downwelling are available from a number of numerical studies including some of the real complexities (e.g. Skliris et al., 2002; Jordi et al., 2005) and from at least one observational study (Flexas et al., 2008). Validated models of specific canyons under upwelling and oscillatory flows are needed or, if possible, more observational studies that estimate flux.

We have made some estimate of cross-shelf fluxes through canyons. However, very few studies have estimated the cross-shelf transport of tracers. The strong biological response observed in the vicinity of canyons (e.g. Bosley et al., 2004) antidotally supports the presence of strong fluxes. A numerical model for Calvi Canyon including a biological model shows a strong phytoplankton response to canyon flow (Skliris and Djenidi, 2006). Furthermore, estimates of the net nitrate flux through regions of canyons are large (Hickey and Banas, 2008). Thus detailed flux estimates for tracer fluxes through canyons are needed to quantify cross-shelf exchange. As much of the water flux through the canyon can simply return to the ocean further downstream, it is important to include a tracer in our models and not simply imply tracer flux from water flux (Jordi et al., 2008). More field observations of tracer fields would be a large asset to determining these net exchange processes over canyons.

\subsection{Role of submarine canyons on dense shelf water cascading}

What is the exact contribution of submarine canyons to the overall export of dense shelf water to the ocean interior? Several Sverdrups of dense bottom water formation are believed to be produced within coastal polynyas around Antarctica (to be compared with about $1 \mathrm{~Sv}$ estimate for the Arctic). Less than $0.5 \mathrm{~Sv}$ might be expected for the Mediterranean Sea. With respect to the export of dense water over smooth continental slope, export of dense water through canyons possibly increases the volume transport because of larger mixing and entrainment of ambient slope waters. To assess this question, the assessment of the interannual variability linked to the external forcings is crucial.

We need to complement our knowledge and understanding on the interactions between the different hydrodynamical processes coexisting in submarine canyons. Various interactions with storm-induced downwelling, along-slope ambient current, tides, sediment resuspension have been observed, and generally appear to strengthen the cascading of dense water.

What is the real impact of dense water flow on the exchanges of biogeochemical elements between the shelf toward the deep basin? Dense shelf water cascading can trans- port very rapidly, but episodically, large quantities of organic and inorganic, dissolved or particulate matter, originating both from the water column or the sediment. Canyons can be perceived as by-passing zones or accumulation zones. In a few cases, it has been shown that it could fuel the deep ecosystems by transporting labile organic matter.

\subsection{Enhanced internal tides and mixing in canyons}

Understanding and quantifying mean flows in canyons is difficult and as described above, much research remains to be done. Quantifying the mechanisms of enhancement of tidal and internal energy adds another level of complexity. Progress may be possible using models and observational techniques designed for research of mixing over mid-ocean ridges.

\section{Summary}

Canyons are conduits of enhanced transport between the shelf and the deep ocean. We have determined much of the dynamics of these flows over the last decades. We need now to quantify the processes and in particular quantify the net fluxes of nutrients and carbon as well as heat and salt.

\section{Appendix A}

\section{Ekman layers for Steady Geostrophic Flow}

Given an along-isobath geostrophic current, a bottom Ekman layer will form and generate cross-isobath flux. The direction of the current (positive or negative) determines the direction of the cross-isobath flux (downslope or upslope). Given a stratified water column, downslope flux carries less dense water under denser water leading to convection and a large thick boundary layer. Upslope flux carries dense water upslope, increasing stratification and leading to a thin boundary layer.

One of the key features defining the properties of these boundary layers is the steepness of the slope $s$ (MacCready and Rhines, 1991). It is defined as the actual slope $\alpha=\nabla_{H} h$ divided by the natural horizontal to vertical scale provided by the stratification and rotation:

$s=\frac{N}{f} \alpha$

where $h$ is the depth of the fluid, $\nabla_{H}=(\partial / \partial x, \partial / \partial y)$ and $N$ is the Brunt-Väisälä frequency. It is this term $s$ that defines the effect of buoyancy in the bottom boundary layer on slopes. For canyons such as Astoria Canyon, Quinault Canyon and Barkley Canyon, $\mathrm{s}$ is of order 3.5-6 over the upper canyon walls and head. 
Consider first conditions for negative flow. For slopes with large $s$ dense water is quickly advected up the slope, causes a retarding baroclinic pressure gradient and halts, or arrests the boundary layer flow. After this point, cross-isobath flow within the boundary layer is negligible and the bottom acts as a free-slip boundary (MacCready and Rhines, 1991).

Under positive flow, light water is advected down the slope causing mixing and deep, stratified boundary layer. This process causes a retarding baroclinic pressure gradient and again, halts the boundary layer flow (MacCready and Rhines, 1991).

For large $s$ recent estimates for the spin-down time for boundary layers give $1.3 / C_{D} N$ for the positive case and $1.9 / C_{D} N$ for the negative case where $C_{D}$ is the bottom drag coefficient (Brink and Lentz, 2008). For Astoria, Barkley and Quinault Canyons, these give spin-down times of 0.71 days (positive) and 1-1.5 days (negative). This is time until the layer is completely arrested; before that time, the upslope flow is considerably reduced over the flat-bottom case (Brink and Lentz, 2008).

\section{Appendix B}

\section{Construction of the canyon map}

The map (Fig. 1) was handmade using the one Minute Grid GEBCO bathymetric atlas by scanning the continental margins of the world ocean. Identifiable shelf-indenting canyons were pinpointed visually, which was obviously dependent of the quality of the subsets of the global atlas. The description was completed using the itemized canyons present in the latest version of Google Ocean. Major large canyon systems as well as isolated smaller canyons were located individually. Networks of close canyons were delineated, and their number was reported to the along-slope distance yielding a linear density per $100 \mathrm{~km}$.

Acknowledgements. This work was invited, encouraged and supported by the Deep Ocean Exchange with the Shelf working group of SCOR. Further financial support to the first author was provided by an NSERC Discovery grant. The manuscript was improved based on comments made by reviewer Don Boyer.

Edited by: J. A. Johnson

\section{References}

Aagaard, K. and Roach, A. T.: Arctic ocean-shelf exchange: Measurements in Barrow Canyon, J. Geophys. Res., 95, 1816318175, 1990.

Allen, S. E.: Topographically generated, subinertial flows within a finite length canyon, J. Phys. Oceanogr., 26, 1608-1632, 1996.

Allen, S. E.: On subinertial flow in submarine canyons: Effect of Geometry, J. Geophys. Res., 105, 1285-1297, 2000.
Allen, S. E.: Restrictions on deep flow across the shelf-break, Surv. Geophys., 25, 221-247, 2004.

Allen, S. E., Vindeirinho, C., Thomson, R. E., Foreman, M. G. G., and Mackas, D. L.: Physical and Biological processes over a submarine canyon during an upwelling event, Can. J. Fish. Aquat. Sci., 58, 671-684, 2001.

Allen, S. E., Dinniman, M. S., Klinck, J. M., Gorby, D. D., Hewett, A. J., and Hickey, B. M.: On vertical truncation errors in terrain following numerical models: Comparison to a laboratory model for upwelling over submarine canyons, J. Geophys. Res., 108, 3003, doi:10.1029/2001JC000978, 2003.

Alvarez, A., Tintoré, J., and Sabatés, A.: Flow modification and shelf-slope exchange induced by a submarine canyon off the northeast Spanish coast, J. Geophys. Res., 101, 12043-12055, 1996.

Ardhuin, F., Pinot, J.-M., and Tintoré, J.: Numerical study of the circulation in a steep canyon off the Catalan coast (western Mediterranean), J. Geophys. Res., 104, 11115-11135, 1999.

Baines, P. G.: Coastal and Regional Currents of Antarctica, in: Encyclopaedia of the Antarctic, edited by: Riffenburgh, R., Routledge, New York, 2006.

Bignami, F., Mattietti, G., Rotundi, A., and Salusti, E.: On a Sugimoto-Whitehead effect in the Mediterranean Sea: sinking and mixing of a bottom current in the Bari Canyon, southern Adriatic Sea, Deep Sea Res. Pt. A, 37, 657-665, doi:10.1016/0198-0149(90)90096-E, 1990.

Bosley, K. L., Lavelle, J. W., Brodeur, R. D., Wakefield, W. W., Emmett, R. L., Baker, E. T., and Rehmke, K. M.: Biological and physical processes in and around Astoria submarine Canyon, Oregon, USA, J. Mar. Sys., 50, 21-37, 2004.

Boyer, D. L., Dhieres, G. C., Didelle, H., Verron, J., Chen, R. R., and Tao, L. J.: Laboratory Simulation of Tidal Rectification over Seamounts - Homogeneous Model, J. Phys. Oceanogr., 21, 1559-1579, 1991.

Boyer, D. L., Zhang, X., and Pérenne, N.: Laboratory observations of rotating, stratified flow in the vicinity of a submarine canyon, Dyn. Atmos. Oceans, 31, 47-72, 2000.

Boyer, D. L., Haidvogel, D. B., and Pérenne, N.: LaboratoryNumerical Model Comparisons of Canyon Flows: A parameter study, J. Phys. Oceanogr., 34, 1588-1609, 2004.

Boyer, D. L., Sommeria, J., Mitrovic, A. S., Pakala, V. K. C., Smirnov, S. A., and Etling, D.: Effects of boundary turbulence on canyon flows forced by periodic along-shelf currents, J. Phys. Oceanogr., 36, 813-826, 2006.

Brink, K. H.: Deep-sea forcing and exchange processes, in: The global coastal ocean, processes and methods, edited by: Brink, K. H. and Robinson, A. R., no. 10 in The Sea, 151-167, John Wiley \& Sons, New York, 1998.

Brink, K. H. and Lentz, S. J.: When does buoyancy arrest neutralize bottom stress over a sloping bottom, in: Ocean Sciences Meeting, 44, Amer. Limnol. Oceanogr. Soc., Abstract, 2008.

Bruno, M., Vázquez, A., Gómez-Enri, J., Vargas, J. M., Lafuente, J. G., Ruiz-Cañavate, A., Mariscal, L., and Vidal, J.: Observations of internal waves and associated mixing phenomena in the Portimao Canyon area, Deep-Sea Res. Pt. II, 53, 1219-1240, 2006.

Canals, M., Puig, P., Durrieu de Madron, X., Heussner, S., Palanques, A., and Fabres, J.: Flushing submarine canyons, Nature, 444, 354-357, doi:10.1038/nature05271.506, 2006.

Canals, M., Danovaro, R., Heussner, S., Lykousis, V., Puig, P., Trin- 
cardi, F., Calafat, A. M., Durrieu de Madron, X., Palanques, A., and Sanchez-Vidal, A.: Cascades in Mediterranean submarine grand canyons, Oceanography, 22, 26-43, 2009.

Carmack, E. C. and Kulikov, E. A.: Wind-forced upwelling and internal Kelvin wave generation in Mackenzie Canyon, Beaufort Sea, J. Geophys. Res., 103, 18447-18458, 1998.

Carter, G. S. and Gregg, M. C.: Intense, variable mixing near the head of Monterey Submarine Canyon, J. Phys. Oceanogr., 32, 3145-3165, 2002.

Chapman, D. C.: The influence of an alongshelf current on the formation and offshore transport of dense water from a coastal polynya, J. Geophys. Res., 105, 24007-24019, 2000.

Chapman, D. C. and Gawarkiewicz, G.: Offshore transport of dense shelf water in the presence of a submarine-canyon, J. Geophys. Res., 100, 13373-13387, 1995.

Chen, X. and Allen, S. E.: Influence of canyons on shelf currents: A theoretical study, J. Geophys. Res., 101, 18043-18059, 1996.

Crawford, W. R. and Dewey, R. K.: Turbulence and mixing sources of nutrients on the Vancouver Island continental-shelf, Atmos.-Ocean, 27, 428-442, 1989.

Darelius, E.: Topographic steering of dense overflows: Laboratory experiments with V-shaped ridges and canyons, Deep-Sea Res., 55, 1021-1034, 2008.

Darelius, E. and Wåhlin, A. K.: Downward flow of dense water leaning on a submarine ridge, Deep-Sea Res. Pt. I, 54, 11731188, 2007.

Darelius, E., Smedsrud, L., Østerhus, S., Foldvik, A., and Gammelsrd, T.: Structure and variability of the Filchner overflow plume, Tellus A, 61, 446-464, doi:10.1111/j.1600-0870.2009.00391.x, 2009.

Davies, A. M. and Xing, J.: Modelling processes influencing shelf edge exchange of water and suspended sediment, Cont. Shelf Res., 25, 973-1001, 2005.

Dawe, J. T. and Allen, S. E.: Resolution of bottom boundary layer transports in a model of canyon upwelling, in: Ocean Sciences Meeting, 85, Amer. Limnol. Oceanogr. Soc. (Abstract), 2008.

De Santis, L., Brancolini, G., Accettella, D., Cova, A., Carburlotto, A., Donda, F., Pelos, C., Zgur, F., and Presti, M.: New insights into geomorphology and depositional processes along the George V Land continental slope and upper rise (East Antarctica), in: Proceedings of the 10th ISAES X (online), edited by: Cooper, A. K., Raymond, C. R., et al., USGS Open-File Report 2007-1047, extend Abstract O61, 2007.

Dinniman, M. S. and Klinck, J. M.: The influence of open versus periodic alongshore boundaries on circulation near submarine canyons, J. Atmos. Oceanic Tech., 19, 1722-1737, 2002.

Dufau-Julliand, C., Marsaleix, P., Petrenko, A., and Dekeyser, I.: Three-dimensional modeling of the Gulf of Lion's hydrodynamics (north-west Mediterranean) during January 1999 (MOOGLI3 Experiment) and late winter 1999: Western Mediterranean Intermediate Water's (WIW's) formation and its cascading over the shelf break, J. Geophys. Res., 109, C11002, doi:10.1029/2003JC002 019, 2004.

Durrieu de Madron, X.: Hydrography and nepheloid structures in the Grand-Rhône canyon, Cont. Shelf Res., 14, 457-477, 1992.

Durrieu de Madron, X., Radakovitch, O., Heussner, S., Loye-Pilot, M. D., and Monaco, A.: Role of the climatological and current variaiblity on shelf-slope exchanges of particulate matter: Evidence form the Rhône continental margin (NW Mediterranean),
Deep-Sea Res. Part. I, 46, 1513-1538, 1999.

Durrieu de Madron, X., Zervakis, V., Theocharis, A., and Georgopoulos, D.: Comments on "Cascades of dense water around the world ocean”, Prog. Oceanogr., 64, 83-90, 2005.

Fer, I. and Adlandsvik, B.: Descent and mixing of the overflow plume from Storfjord in Svalbard: an idealized numerical model study, Ocean Sci., 4, 115-132, 2008,

http://www.ocean-sci.net/4/115/2008/.

Fer, I., Skogseth, R., Haugan, P. M., and Jaccard, P.: Observations of the Storfjorden overflow, Deep-Sea Res., 50, 1283-1303, 2003.

Flexas, M. M., Boyer, D. L., Espino, M., Puigdefàbregas, J., Rubio, A., and Company, J. B.: Circulation over a submarine canyon in the NW Mediterranean, J. Geophys. Res., 113, C12002, doi:10.1029/2006JC003998, 2008.

Fohrmann, H. H., Backhaus, J. O., Blaume, F., and Romohr, J.: Sediments in bottom-arrested gravity plumes: Numerical case studies, J. Phys. Oceanogr., 28, 2250-2274, 1998.

Freeland, H. J. and Denman, K. L.: A topographically controlled upwelling center off southern Vancouver Island, J. Mar. Res., 40, 1069-1093, 1982.

Geyer, F., Fer, I., and Eldevik, T.: Dense overflow from an Arctic fjord: Mean seasonal cycle, variability and wind influence, Cont. Shelf Res., 29, 2110-2121, 2009.

Gordon, A. L., Orsi, A. H., Muench, R., Huber, B. A., Zambianchi, E., and Visbeck, M.: Western Ross Sea continental slope gravity currents, Deep-Sea Res. Pt. II, 56, 796-817, doi:10.1016/j.dsr2.2008.10.037, 2009.

Gregg, M. C., Carter, G. S., and Kunze, E.: Intense, variable mixing near the head of Monterey submarine canyon (32, 3145, 2002), J. Phys. Oceanogr., 35, 1712-1715, 2005.

Guan, X., Ou, H.-W., and Chen, D.: Tidal effect on the dense water discharge: Part 2 - A numerical study, Deep-Sea Res. Pt. II, 56, 884-894, doi:10.1016/j.dsr2.2008.10.028, 2009.

Haidvogel, D. B.: Cross-shelf exchange driven by oscillatory barotropic currents at an idealized coastal canyon, J. Phys. Oceanogr., 35, 1054-1067, 2005.

Haidvogel, D. B. and Beckmann, A.: Form stress and coastal ocean models, in: Flow-topography interactions, edited by: Muller, P. and Henderson, D., 'Aha Huliko'a winter workshop, 191-197, 1995.

Haney, R. L.: On the pressure gradient force over steep topography in sigma coordinate ocean models, J. Phys. Oceanogr., 21, 610 619, 1991.

Hickey, B. M.: Coastal submarine canyons, in: Topographic effects in the ocean, 'Aha Hulika'a, proceedings of the Hawaiian Winter Workshop, University of Hawaii, 1995.

Hickey, B. M.: The response of a steep-sided narrow canyon to strong wind forcing, J. Phys. Oceanogr., 27, 697-726, 1997.

Hickey, B. M. and Banas, N. S.: Why is the northern end of the California current system so productive?, Oceanogr., 21, 90-107, 2008.

Hickey, B. M., Baker, E., and Kachel, N.: Suspended particle movement in and around Quinault Submarine Canyon, Marine Geol., 71, 35-83, 1986.

Hill, A. E., Souza, A. J., Jones, K., Simpson, J. H., Shapiro, G. I., McCandliss, R., Wilson, H., and Leftley, J.: The Malin cascade in winter 1996, J. Mar. Res., 56, 87-106, 1998.

Hotchkiss, F. S. and Wunsch, C.: Internal waves in Hudson Canyon 
with possible geological implications, Deep Sea Res., 29, 415442, 1982

Huhn, O., Hellmer, H. H., Rhein, M., Rodehacke, C. B., Roether, W., Schodlok, M. P., and Schróder, M.: Evidence of deep- and bottom-water formation in the western Weddell Sea, Deep-Sea Res. II, 55, 1098-1116, 2008.

Ivanov, V. V., Shapiro, G. I., Huthnance, J. M., Alyenik, D. L., and Golovin, P. N.: Cascades of dense water around the world ocean, Prog. Oceanogr., 60, 47-98, 2004.

Jachec, S. M., Fringer, O. B., Gerritsen, M. G., and Street, R. L.: Numerical simulation of internal tides and resulting energetics within Monterey Bay and the surrounding area, Geophys. Res. Lett., 33, L12605, doi:10.1029/2006GL026314, 2006.

Jaramillo, U. S.: Numerical simulation of flow in a laboratory tank using a z-coordinate numerical model, Master's thesis, University of British Columbia, 2005.

Jordi, A., Orfila, A., Basterretxea, G., and Tintore, J.: Shelf-slope exchanges by frontal variability in a steep submarine canyon, Prog. Oceangr., 66, 120-141, 2005.

Jordi, A., Klinck, J. M., Basterretxea, G., Orfila, A., and Tintoré, J.: Estimation of shelf-slope exchanges induced by frontal instability near submarine canyons, J. Geophys. Res., 113, C05016, doi:10.1029/2007JC004207, 2008.

Kämpf, J.: Impact of multiple submarine channels on the descent of dense water at high latitudes, J. Geophys. Res.-Oceans, 105, 8753-8773, 2000.

Kämpf, J.: Cascading-driven upwelling in submarine canyons at high latitudes, J. Geophys. Res. Oceans, 110, C02007, doi:10.1029/2004JC002554, 2005.

Kämpf, J.: Transient wind-driven upwelling in a submarine canyon: A process-oriented modeling study, J. Geophys. Res., 111, C11011, doi:10.1029/2006JC003497, 2006.

Kämpf, J.: On the magnitude of upwelling fluxes in shelf-break canyons, Cont. Shelf Res., 27, 2211-2223, 2007.

Kämpf, J.: On the interaction of time-variable flows with a shelfbreak canyon, J. Phys. Oceanogr., 39, 248-260, 2009.

Kämpf, J., Backhaus, J. O., and Fohrmann, H.: Sediment-induced slope convection: two-dimensional numerical case studies, J. Geophys. Res., 104, 20509-20522, 1999.

Keen, T. R. and Allen, S. E.: Baroclinic oscillations on the Louisiana continental shelf during Hurricane Andrew, J. Geophys. Res., 105, 26203-26244, 2000.

Killworth, P. D.: Deep convection in the world ocean, Rev. Geophys. Space Phys., 21, 1-26, 1983.

Kinsella, E. D., Hay, A. E., and Denner, W. W.: Wind and topographic effects on the Labrador current at Carson canyon, J. Geophys. Res., 92, 10853-10869, 1987.

Klinck, J. M.: The influence of a narrow transverse canyon on initially geostrophic flow, J. Geophys. Res., 93, 509-515, 1988.

Klinck, J. M.: Geostrophic adjustment over submarine canyons, J. Geophys. Res., 94, 6133-6144, 1989.

Klinck, J. M.: Circulation near submarine canyons: A modeling study, J. Geophys. Res., 101, 1211-1223, 1996.

Klinck, J. M., Hickey, B. M., Dinniman, M. S., and Allen, S. E.: Model-data comparison of flow over realistic topography in a region with coastal submarine canyons, in: EOS Trans., 80(49), OS22L, Abstract, 1999.

Kremenetskiy, V. O., Stroganov, O., Emelianov, M., GarciaLadona, E., Palanques, A., Poyarkov, S., and Zatsepin, A. G.:
Frontal currents in the rotating fluid over sloping bottom: in fluence of canyons, in: Proceedings of Fluxes and Structures in Fluids, edited by: Chashechkin, Y. D. and Baydulov, V. G., Institute for Problems in Mechanics of the RAS, Moscow, Russia, 111-114, 2004.

Kunze, K., Rosenfeld, L. K., Carter, G. S., and Gregg, M. C.: Internal waves in Monterey submarine canyon, J. Phys. Oceanogr., 32, 1890-1913, 2002.

Lafuente, J. G., Sarhan, T., Vargas, M., Vargas, J. M., and Plaza, F.: Tidal motions and tidally induced fluxes through La Linea submarine canyon, western Alboran Sea, J. Geophys. Res., 104, 3109-3119, 1999.

Lee, I. H., Lien, R. C., Liu, J. T., and Chuang, W. S.: Turbulent mixing and internal tides in Gaoping (Kaoping) Submarine Canyon, Taiwan, J. Mar. Sys., 76, 383-396, 2009.

MacCready, P. and Rhines, P. B.: Buoyant inhibition of Ekman transport on a slope and its effect on stratified spin-up, J. Fluid Mech., 223, 631-661, 1991.

Mirshak, R. and Allen, S. E.: Spin-up and the effects of a submarine canyon: applications to upwelling in Astoria Canyon, J. Geophys. Res., Oceans, 110, C02013, doi:10.1029/2004JC002578, 2005.

Münchow, A. and Carmack, E. C.: Synoptic flow and density observations near an Arctic shelf break, J. Phys. Oceanogr., 27, 1402 1419, 1997.

Niemann, H., Richter, C., Jonkers, H. M., and Badran, M. I.: Red Sea gravity currents cascade near-reef phytoplankton to the twilight zone, Mar. Ecol. Prog. Ser., 269, 91-99, 2004.

Padman, L., Howard, S. L., Orsi, A. H., and Muench, R. D.: Tides of the northwestern Ross Sea and their impact on dense outflows of Antarctic Bottom Water, Deep-Sea. Res. II, 13-14, 818-834, doi:10.1016/j.dsr2.2008.10.026, 2009.

Palanques, A., García-Ladona, E., Gomis, D., Martin, J., Marcos, M., Pascual, A., Puig, P., Gili, J.-M., Emelianov, M., Monserrat, S., Guillén, J., Tintoré, J., Segura, M., Jordi, A., Ruiz, S., Basterretsea, G., Font, J., Blasco, D., and Pagès, F.: General patterns of circulation, sediment fluxes and ecology of the Palamós ( $\mathrm{La}$ Fonera) submarine canyon, northwestern Mediterranean, Prog. Oceanogr., 66, 89-119, 2005.

Pascual, A., Gomis, D., Haney, R. L., and Ruiz, S.: A quasigeostrophic analysis of a meander in the Palamos Canyon: Vertical velocity, geopotential tendency and a relocation technique, J. Phys. Oceanogr., 34, 2274-2287, 2004.

Perenne, N., Haidvogel, D. B., and Boyer, D. L.: Laboratorynumerical model comparisons of flow over a coastal canyon, J. Atmos. Ocean. Tech., 18, 235-255, 2001.

Perenne, N., Lavelle, J. W., Smith, D. C. I., and Boyer, D. L.: Impulsively started flow in a submarine canyon: Comparison of results from laboratory and numerical models, J. Atmos. Ocean. Tech., 18, 1698-1718, 2001b.

Petruncio, E. T., Rosenfeld, L. K., and Paduan, J. D.: Observations of the internal tide in Monterey Canyon, J. Phys. Oceanogr., 28, 1873-1903, 1998.

Petruncio, E. T., Paduan, J. D., and Rosenfeld, L. K.: Numerical simulations of the internal tide in a submarine canyon, Ocean Model., 4, 221-248, 2002.

Pickart, R. S., Weingartner, T. J., Pratta, L. J., Zimmermannc, S., and Torresa, D. J.: Flow of winter-transformed Pacific water into the Western Arctic, Deep Sea Res. Pt. II, 52, 3175-3198, 2005. 
Puig, P., Palanques, A., Orange, D. L., Lastras, G., and Canals, M.: Dense shelf water cascades and sedimentary furrow formation in the Cap de Creus Canyon, northwestern Mediterranean Sea, Cont. Shelf Res., 28, 2017-2030, doi:10.1016/j.csr.2008.05.002, 2008.

Quadfasel, D., Rudels, B., and Kurz, L.: Outflow of dense water from a Svalbard fjord into the Fram Strait, Deep-Sea Res., 35, 1143-1150, 1988.

Rennie, S. J., McCauley, R. D., and Pattiaratchi, C. B.: Thermal structure above the Perth Canyon reveals Leeuwin Current, Undercurrent and weather influences and the potential for upwelling, Mar. Freshw. Res., 57, 849-861, 2006.

Rosenfeld, L. K., Schwing, F. B., Garfield, N., and Tracy, D. E.: Bifurcated Flow From An Upwelling Center - A Cold-Water Source For Monterey Bay, Cont. Shelf Res., 14, 931-964, 1994.

Rubino, A., Budillon, G., Pierini, S., and Spezie, G.: A model for the spreading and sinking of the Deep Ice Shelf Water in the Ross Sea, Antarctic Sci., 15, 25-30, doi:10.1017/S0954102003001020, 2003.

Saucier, F. J.: Tidal circulation and buoyancy effects in the St. Lawrence Estuary, Atmos.-Ocean, 38, 505-556, 2000.

Schauer, U. and Fahrbach, E.: A dense bottom water plume in the western Barents Sea: downstream modification and interannual variability, Deep-Sea Res. Pt. I, 46, 2095-2108, 1999.

Shaffer, G.: A mesoscale study of coastal upwelling variability off NW-Africa, Meteor Forsch.-Ergebnisse, 17, 21-72, 1976.

Shaw, P. T. and Chao, S. Y.: Effects of a baroclinic current on a sinking dense water plume from a submarine canyon and heton shedding, Deep-Sea Res. Pt. I, 50, 357-370, 2003.

She, J. and Klinck, J. M.: Flow near submarine canyons driven by constant winds, J. Geophys. Res., 105, 28671-28694, 2000.

Skliris, N. and Djenidi, S.: Plankton dynamics controlled by hydrodynamic processes near a submarine canyon off NW Corsican coast: A numerical modelling study, Cont. Shelf Res., 26, 13361358, 2006.

Skliris, N., Goffart, A., Hecq, J. H., and Djenidi, S.: Shelfslope exchanges associated with a steep submarine canyon off Calvi (Corsica, NW Mediterranean Sea), J. Geophys. Res., 106, 19883-19901, 2001.

Skliris, N., Hecq, J. H., and Djenidi, S.: Water fluxes at an ocean margin in the presence of a submarine canyon, J. Mar. Sys, 32, 239-251, 2002.

Skogseth, R., Smedsrud, L. H., Nilsen, F., and Fer, I.: Observations of hydrography and downflow of brine-enriched shelf water in the Storfjorden polynya, Svalbard, J. Geophys. Res., 113, C08049, doi:10.1029/2007JC004452, 2008.

Sobarzo, M., Figueroa, M., and Djurfeldt, L.: Upwelling of subsurface water into the rim of the Biobio submarine canyon as a response to surface winds, Cont. Shelf Res., 21, 279-299, 2001.

Taylor, G. I.: Experiments on the motion of solid bodies in rotating fluids, Proc. Roy. Soc. A, 104, 213-218, 1923.

Trincardi, F., Foglini, F., Verdicchio, G., Asioli, A., Correggiari, A., Minisini, D., Piva, A., Remia, A., Ridente, D., and Taviani, M.: The impact of cascading currents on the Bari Canyon System, SW-Adriatic Margin (Central Mediterranean), Mar. Geol., 246, 208-230, 2007.
Ulses, C., Estournel, C., Puig, P., Durrieu de Madron, X., and Marsaleix, P.: Dense shelf water cascading in the northwestern Mediterranean during the cold winter 2005: Quantification of the export through the Gulf of Lion and Catalan margin, Geophys. Res. Lett., 35, L07610, doi:10.1029/2008GL033257, 2008a.

Ulses, C., Estournel, C., Bonnin, J., Durrieu de Madron, X., and Marsaleix, P.: Impact of storms and dense water cascading on shelf-slope exchanges in the Gulf of Lion (NW Mediterranean), J. Geophys. Res., 113, C02010, doi:10.1029/2006JC003795, 2008b.

Vilibic, I. and Santic, D.: Deep water ventilation traced by Synechococcus cyanobacteria, Ocean Dynam., 58, 119-125, 2008.

Vilibic, I. and Supic, N.: Dense water generation on a shelf: the case of the Adriatic Sea, Ocean Dynam., 55, 403-415, 2005.

Wåhlin, A. K.: Topographic steering of dense currents with application to submarine canyons, Deep-Sea Res., 49, 305-320, 2002.

Wåhlin, A. K.: Downward channeling of dense water in topographic corrugations, Deep-Sea Res., 51, 577-590, 2004.

Wåhlin, A. K., Darelius, E., Cenedese, C., and Lane-Serff, G. F.: Laboratory observations of enhanced entrainment in dense overflows in the presence of submarine canyons and ridges, Deep-Sea Res., 55, 737-750, 2008.

Wang, Q., Danilov, S., and Schröter, J.: Bottom water formation in the southern Weddell Sea and the influence of submarine ridges: Idealized numerical simulations, Ocean Model., 28, 5059, 2009

Waterhouse, A. F., Allen, S. E., and Bowie, A. W.: Upwelling flow dynamics in long canyons at low Rossby Number, J. Geophys. Res., C05004, doi:10.1029/2008JC004956, 2009.

Weingartner, T. J., Cavalieri, D. J., Aagaard, K., and Sasaki, Y.: Circulation, dense water formation, and outflow on the northeast Chukchi shelf, J. Geophys. Res., 103, 7647-7661, 1998.

Whiteman, C. D. and Doran, J. C.: The relationship between overlying synoptic-scale flows and winds within a valley, J. Appl. Meteor., 32, 1669-1682, 1993.

Williams, G. D., Bindoff, N. L., Marsland, S. J., and Rintoul, S. R.: Formation and export of dense shelf water from the Adélie Depression, East Antarctica, J. Geophys. Res., 113, C04039, doi:10.1029/2007JC004346, 2008.

Williams, W. J., Carmack, E. C., Shimada, K., Melling, H., Aagarrd, K., Macdonald, R. W., and Ingram, R. G.: Joint effects of wind and ice motion in forcing upwelling in Mackenzie Trough, Beaufort Sea, Cont. Shelf Res., 26, 2352-2366, 2006.

Wunsch, C. and Webb, S.: Climatology of deep ocean internal waves, J. Phys. Oceanogr., 9, 235-243, 1979.

Yuan, D.: A numerical study of barotropicly forced intrusion in DeSoto Canyon, J. Geophys. Res., 107, C03010, doi:10.1029/2001JC000793, 2002. 